\title{
AGRONOMIC EFFICIENCY OF THE INTERCROPPING OF ARUGULA WITH CARROT UNDER DIFFERENT POPULATION COMBINATIONS ${ }^{1}$
}

\author{
THAÍZA MABELLE DE VASCONCELOS BATISTA ${ }^{2}$, FRANCISCO BEZERRA NETO ${ }^{3 *}$, ÍTALO NUNES SILVA ${ }^{3}$, \\ MAIELE LEANDRO DA SILVA ${ }^{3}$; ELIANE QUEIROGA DE OLIVEIRA ${ }^{4}$; AURÉLIO PAES BARROS JÚNIOR ${ }^{3}$
}

\begin{abstract}
The objective of this study was to evaluate the agronomic efficiency of intercropping combinations of carrot and arugula at different population densities in bicropping in the semi-arid conditions of the Brazilian Northeast. The study was conducted at the "Rafael Fernandes" Experimental Farm of the Universidade Federal Rural do Semi-Árido (UFERSA) during the period September 2011 to February 2012. The experimental design was of randomized complete blocks with treatments arranged in a 4 x 4 factorial scheme with four replications. The combinations were four population densities of carrot (40,60, 80 and $100 \%$ of the recommended population in sole crop - RPSC) with four population densities of arugula (40, 60, 80 and $100 \%$ of the RPSC). The recommended population densities for sole crops of carrot and arugula are 500,000 and 1,000,000 plants per hectare, respectively. All treatments were fertilized with hairy woodrose (Merremia aegyptia L.), a spontaneous species of the Caatinga biome. The highest agronomic efficiency of carrot intercropped with arugula in bicropping was achieved in the combination of $40 \%$ of RPSC for the carrot and $100 \%$ of RPSC for the arugula. The commercial maximum yield $\left(33.74 \mathrm{t} \mathrm{ha}^{-1}\right)$ of carrot roots and the maximum yields of arugula green mass ( 8.06 and $\left.2.67 \mathrm{t} \mathrm{ha}^{-1}\right)$ in both cultivations were also obtained in the combination of population densities of $40 \%$ of RPSC for carrot and $100 \%$ of RPSC for arugula.
\end{abstract}

Keywords: Strip intercropping. Daucus carota. Eruca sativa. Merremia aegyptia.

\section{EFICIÊNCIA AGRONÔMICA DO CONSÓRCIO DE RÚCULA COM CENOURA SOB DIFERENTES POPULAÇÕES}

RESUMO - O objetivo deste estudo foi avaliar a eficiência agronômica de combinações de cenoura e rúcula em diferentes densidades populacionais em bicultivo nas condições semiáridas do Nordeste brasileiro. O estudo foi realizado na Fazenda Experimental "Rafael Fernandes" da Universidade Federal Rural do Semi-Árido (UFERSA), durante o período de setembro de 2011 a fevereiro de 2012. O delineamento experimental foi de blocos casualizados, com os tratamentos arranjados em esquema fatorial 4 x 4 com quatro repetições. As combinações foram quatro densidades populacionais de cenoura (40,60, 80 e 100\% da população recomendada em cultivo solteiro - PRCS) com quatro densidades populacionais de rúcula (40, 60, 80 e 100\% da PRCS). As densidades populacionais recomendadas para os cultivos solteiros de cenoura e rúcula são 500.000 e 1.000 .000 de plantas por hectare, respectivamente. Todos os tratamentos foram adubados com jitirana (Merremia aegyptia L.), uma espécie espontânea do bioma Caatinga. A maior eficiência agronômica da cenoura consorciada com a rúcula em bicultivo foi alcançada na combinação populacional de $40 \%$ da PRCS da cenoura e $100 \%$ da PRCS de rúcula. A produção comercial máxima $\left(33,74 \mathrm{t} \mathrm{ha}^{-1}\right)$ de raízes de cenoura e os rendimentos máximos de massa verde $\left(8,06\right.$ e 2,67 $\left.\mathrm{t} \mathrm{ha}^{-1}\right)$ de rúcula nos dois cultivos foram obtidos também na combinação de densidades populacionais de $40 \%$ da PRCS de cenoura e $100 \%$ da PRCS de rúcula.

Palavras-chave: Associação de culturas em faixas. Daucus carota. Eruca sativa. Merremia aegyptia.

\footnotetext{
"Corresponding author

${ }^{1}$ Received for publication in $02 / 27 / 2015$; accepted in $10 / 23 / 2015$.

Paper extracted from the doctoral dissertation of the first author.

${ }^{2}$ Department of Education, Instituto Federal de Educação, Ciência e Tecnologia do Rio Grande do Norte, Apodi, RN, Brazil; thaizamabelle@hotmail.com.

${ }^{3}$ Department of Crop Science, Universidade Federal Rural do Semi-Árido, Mossoró, RN, Brazil; bezerra@ufersa.edu.br, italonunessilva@gmail.com,maiele@ufersa.edu.br; aurelio.barros@ufersa.edu.br.

${ }^{4}$ Department of Education, Instituto Federal de Educação, Ciência e Tecnologia, Sousa, PB, Brazil; eliqueiroga04@yahoo.com.br.
} 


\section{INTRODUCTION}

In northeastern Brazil, carrot and arugula come constitute two extremely important crops in cropping systems with green fertilizers due to their good agronomic performance and their social, economic and nutritional characteristics. The development of green cropping systems, with a view to optimizing productivity, has required farmers to reduce or even eliminate the shortcomings in the production (MONTEZANO; PEIL, 2006). Among the many multiple cropping possibilities, intercropping systems have received special attention, mainly because of the richness of their ecological interactions, plant population, spatial arrangement and management of the crops in the field. These are in contrast to modernized agricultural systems, which are based on monoculture, intensive use of capital and products originating from the industrial sector, such as synthetic fertilizers and pesticides (SANTOS, 1998).

Intercropping systems have a number of advantages, such as increased biological diversity, better land use and reduced environmental inputs, decreased production costs and the possibility of greater economic returns, greater protection and soil cover and greater well-being of rural workers, among others (CECÍLIO FILHO; MAY, 2002; SOUZA; REZENDE, 2003; MAHAPATRA, 2011; MOUSAVI; ESKANDARI, 2011).

The success of the systems can be determined by a number of agronomic parameters that affect interactions between species. These parameters include: overall population density, availability of resources and the type of intercropping system used (GLIESSMAN, 1998; HATFIELD; KARLEN, 1994; MAZAHERI; MADANI; OVEYSI, 2006).

The total population densities of intercropping systems and the relative proportions of the component cultures are important in determining the yield and efficiency of the crop production in combination. Lopes et al. (2008) report that the good management of this factor increases efficiency in the use of the inputs applied as fertilizers and pesticides and the available resources such as water, light and nutrients and results in increased productivity. Optimization of plant density has been used in many cultivated species and its use in vegetable crops has been growing lately.

Barros Júnior et al. (2005), working with the bicropping of carrot and lettuce, obtained an increase in the total and commercial productivity of carrot and in the dry mass of the lettuce shoot using increased population densities of the component crops. Thus, the maximization of the advantages of an intercropped system is a question of maximizing the degree of complementarity between the component crops and minimizing intercultural competition.

In this context, this study aimed to evaluate the agronomic efficiency of the cultivation of arugula intercropped with carrot at different population densities of the component crops in the semi-arid conditions of Mossoró-RN.

\section{MATERIAL AND METHODS}

The study was conducted in the experimental area of the Rafael Fernandes Farm belonging to the Universidade Federal do Semi-Árido (UFERSA), located in Alagoinha district, $20 \mathrm{~km}$ from the city of Mossoró-RN ( $5^{\circ} 03^{\prime} 37^{\prime \prime} \mathrm{S}$ and $37^{\circ} 23^{\prime} 50^{\prime \prime} \mathrm{W}$ Gr) from September 2011 to February 2012. In this area, soil samples were collected at a $0-20 \mathrm{~cm}$ depth and then sent to the Laboratory of Soil Fertility and Plant Nutrition of the UFERSA. The soil characteristics were as follows: $\mathrm{pH}$ (water) = 6.8; $\mathrm{P}=6.3 \mathrm{cmol}_{\mathrm{c}} \mathrm{dm}^{-3} ; \mathrm{K}=85.2 \mathrm{mg} \mathrm{\textrm {dm } ^ { - 3 }}$; $\mathrm{Ca}=2.01 \mathrm{cmol}_{\mathrm{c}} \mathrm{dm}^{-3} ; \mathrm{Mg}=1.09 \mathrm{cmol}_{\mathrm{c}} \mathrm{dm}^{-3} ;$ $\mathrm{Na}=35.9 \mathrm{mg} \mathrm{dm}{ }^{-3} ; \mathrm{SB}=3.47 \mathrm{cmol}_{\mathrm{c}} \mathrm{dm}^{-3}$ and $\mathrm{V}=91 \%$.

The experiment used a randomized block design with treatments arranged in a factorial $4 \times 4$ design, with four replications. The first factor consisted of four population densities of carrot plants (40, 60, 80 and $100 \%$ of the recommended population in sole crop - RPSC) and the second factor was four population densities of arugula plants (40, 60, 80 and $100 \%$ of the RPSC). The recommended planting density of plants for cultivations in the region is 500,000 plants per hectare for carrot (BEZERRA NETO et al. 2012) and 1,000,000 plants per hectare for arugula (FREITAS et al., 2009). The intercropping was established in alternating bands using $50 \%$ of the area for carrot and $50 \%$ of the area for arugula, where each plot consisted of two strips of four rows of each crop, flanked by two rows of one crop at one side and two rows of the other crop at the other side (Figure 1).

The plots used in intercropping had a total area of $2.88 \mathrm{~m}^{2}$, with a harvest area of $1.60 \mathrm{~m}^{2}$. Plants were spaced at $0.20 \mathrm{~m}$ between the rows and within the row spacing varied according to the population density of carrot or arugula studied. The harvest area was composed of the two central strips of plants, excluding the first two and the last two plants of each row, which were used as borders. In each block, plots were planted with carrot and arugula as the sole crop to obtain the efficiency indices of the system. Each sole crop plot was established by planting six rows with a total area of $1.44 \mathrm{~m}^{2}$ and a harvest area of $0.80 \mathrm{~m}^{2}$, in the spacing $0.20 \mathrm{~m} \times 0.05 \mathrm{~m}$ for arugula and $0.20 \mathrm{~m} \times 0.10 \mathrm{~m}$ for carrot. The harvest area was composed of the four central rows of plants, excluding the first and last plants of each row, which were used as borders. The cultivars of carrot and arugula planted were 'Brasília' and 'Cultivada', respectively.

Rev. Caatinga, Mossoró, v. 29, n. 1, p. 76 - 84, jan. - mar., 2016 

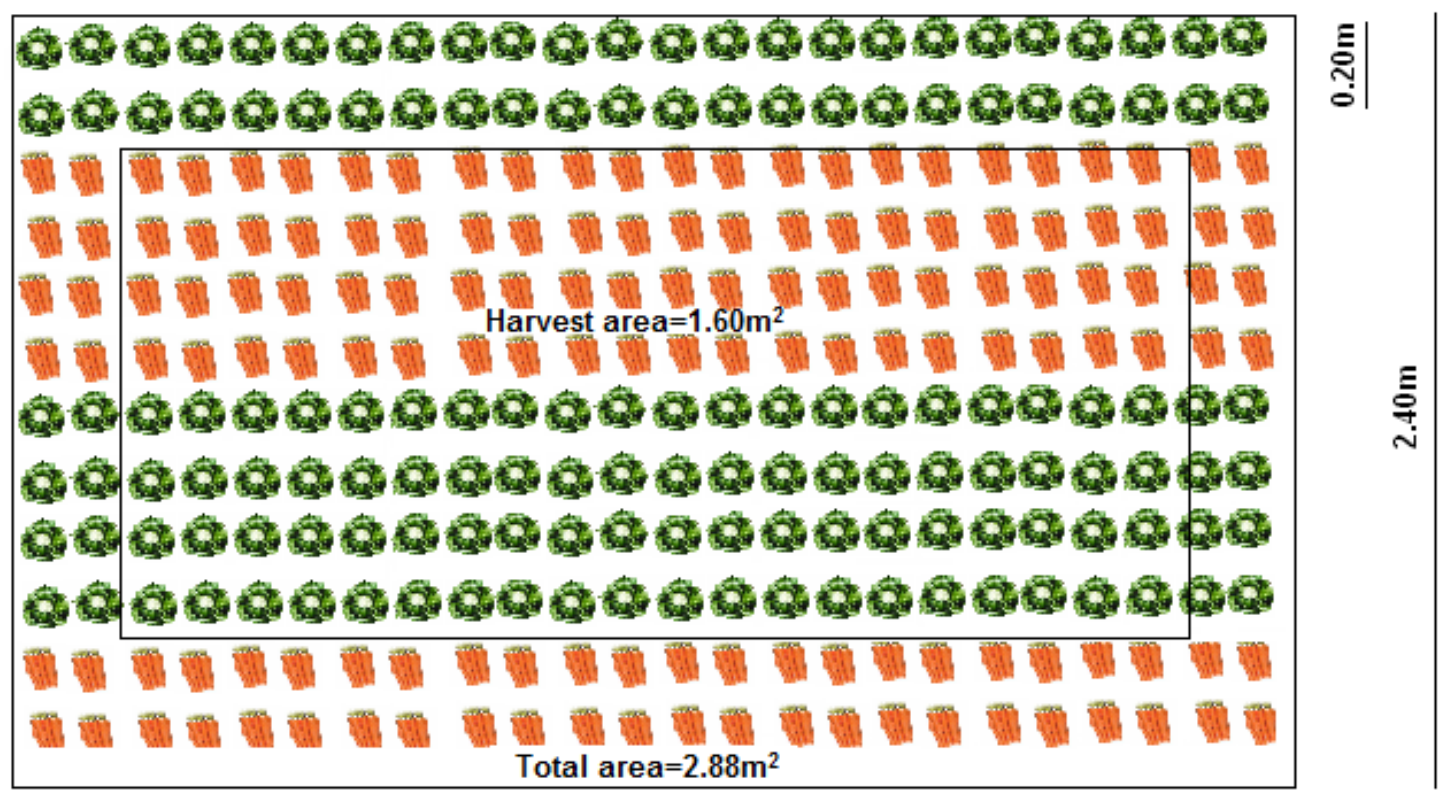

$\underline{0.05 m}$

\begin{abstract}
$1.20 \mathrm{~m}$
$\begin{aligned} & \text { Figure 1. Graphical representation of an experimental plot of carrot }( \\ & \text { strips. Mossoró-RN, UFERSA } 2012 \text {. }\end{aligned}$ strips. Mossoró-RN, UFERSA 2012.
\end{abstract}

The soil preparation consisted of manual cleaning of the experimental area with the aid of a hoe, followed by harrowing and the construction of four beds, with dimensions of $42.0 \mathrm{~m} \mathrm{x} 1.20 \mathrm{~m}$ each. One solarization with 30 micron 'Vulcabrilho Bril Fles' clear plastic was performed for 45 days, in order to reduce the population of soil phytopathogens and reduce the appearance of dumping off that can harm the productivity of the crops (OLIVEIRA, 2012).

Green manuring with hairy woodrose (Merremia aegyptia L.) was performed in the cultivated area for all treatments. The carrot plots in both the intercropping systems and the single crop plots were fertilized with $20 \mathrm{t} \mathrm{ha}^{-1}$ of hairy woodrose biomass, $50 \%$ of the amount being incorporated into the soil at 20 days before planting of the crops, and the remaining $50 \%$ incorporated 55 days after sowing (OLIVEIRA et al., 2012). For both cultures of arugula, $12 \mathrm{t} \mathrm{ha}^{-1}$ of hairy woodrose biomass, as optimized by Linhares et al. (2008), was incorporated 20 days before each arugula planting. Hairy woodrose was collected in several areas of the municipality of Mossoró-RN, before the start of flowering (between April and July 2011). Then, the collected material was triturated in a forage machine into two centimeters pieces and left to dry at ambient conditions for about four days until reaching hay point (about $10 \%$ humidity), and subsequently stored before use (OLIVEIRA, 2011).

Five simple samples of the green manure were taken and combined into a single composite sample, which was sent to the Laboratory of Soil, Water and Plant of the UFERSA and analyzed. The results obtained were as follows: $\mathrm{C}=31.90 \mathrm{~g} \mathrm{~kg}^{-1}$; $\mathrm{P}=3.20 \mathrm{~g} \mathrm{~kg}^{-1} ; \mathrm{K}=46.40 \mathrm{~g} \mathrm{~kg}^{-1} ; \mathrm{Ca}=1.8 \mathrm{~g} \mathrm{~kg}^{-1} ;$ $\mathrm{Mg}=3.3 \mathrm{~g} \mathrm{~kg}^{-1}, \mathrm{Fe}=428 \mathrm{mg} \mathrm{kg}^{-1} ; \mathrm{Zn}=20 \mathrm{mg} \mathrm{kg}^{-1}$; $\mathrm{Cu}=11 \mathrm{mg} \mathrm{kg}^{-1}$ and $\mathrm{Mn}=48 \mathrm{mg} \mathrm{kg}^{-1}$.

Weeds were controlled by hand weeding. Two irrigations daily were carried out by microsprinkler system with a water sheet of about $8 \mathrm{~mm} \mathrm{~d}^{-1}$ (PORTO et al., 2011).

The carrot and arugula sowing took place on 10 and 11 October 2011, in holes about three centimeters deep, placing three to four seeds per hole. The thinning of the arugula was done at eight days after planting, leaving two plants per hill, while thinning of the carrot was carried out at 21 days after planting, leaving one plant per hole. The arugula harvest took place on 15 and 16 November 2011 (35 days after sowing). The arugula strips were kept clean by hand weeding until the second seeding.

The second planting of arugula was performed on 9 and 10 January 2012, 90 days after the carrot sowing. The planting procedures, thinning, weeding and irrigation were the same as for the first cropping. At the end of the 35-day cycle the harvest was performed on 13 and 14 February. The carrot harvest took place on 23 and 24 January 2012 (105 days after sowing).

The characteristics evaluated in the carrots were: dry mass of shoots and roots (obtained from a sample of twelve plants from the harvest area of the plot, where the dry mass was determined by heating 
in an oven with forced air circulation at $65^{\circ} \mathrm{C}$ until constant weight and expressed in $\mathrm{t} \mathrm{ha}^{-1}$ ); total root productivity (obtained from the fresh weight of plant roots of the harvest area, and expressed in $\mathrm{t} \mathrm{ha}^{-1}$ ); commercial productivity (obtained from the fresh weight of the plant roots of the harvest area free of cracks, bifurcations, nematodes and mechanical damage, expressed in $\mathrm{t} \mathrm{ha}^{-1}$ ) and the classified productivity of the roots (assessed according to the greatest length and largest diameter), in the classes: long (with a length of 17 to $25 \mathrm{~cm}$ and diameter smaller than $5 \mathrm{~cm}$ ), medium (with a length of 12 to $17 \mathrm{~cm}$ and a diameter greater than $2.5 \mathrm{~cm}$ ), short (with a length of 5 to $12 \mathrm{~cm}$ and a diameter larger than $1 \mathrm{~cm}$ ) and scrap (roots falling outside the other measurement categories), as per VIEIRA et al. (2005).

The characteristics evaluated in the arugula were: green mass yield (measured by the fresh mass of shoots of all plants in the harvest area, and expressed in $\mathrm{t} \mathrm{ha}^{-1}$ ) and dry mass of shoot (obtained from a sample of twenty plants where the dry mass was determined in an oven with forced air circulation at $65^{\circ} \mathrm{C}$ until constant weight and expressed in $\mathrm{t}$ ha $\left.{ }^{1}\right)$. The characteristics were determined separately for each arugula cropping.

The equivalent production index of carrot (the combined index of the two cultures) was determined to evaluate the studied intercropping systems. It was obtained by the following equation: IPEc $=\mathrm{Y}_{\mathrm{c}}+\mathrm{r} \mathrm{Y}_{\mathrm{a}}$ (RAMALHO; OLIVEIRA; GARCIA, 1983), where $\mathrm{EPI}_{\mathrm{c}}$ is the equivalent production index of carrot $(\mathrm{t}$ ha $\left.{ }^{-1}\right)$; $Y_{c}$ is the commercial root productivity of carrot $\left(\mathrm{t} \mathrm{ha}{ }^{-1}\right) ; \mathrm{Y}_{\mathrm{a}}$ is the green arugula mass yield $\left(\mathrm{t} \mathrm{ha}^{-1}\right)$ and $\mathrm{r}$ is the ratio between carrot prices $\left(\mathrm{R} \$ 0.80 \mathrm{~kg}^{-1}\right)$ and arugula (R\$ $1.40 \mathrm{~kg}^{-1}$ ). The prices of the vegetable crops corresponded to the average prices received by producers in the western region of the Rio Grande do Norte state, in the period 2008-2012.

Regression analyses were performed on the assessed characteristics in the two cultures and in the equivalent production index of carrot, with the response curve adjustment procedures performed in these characteristics as a function of the population densities of the vegetable crops using Table Curve software (JANDEL SCIENTIFIC, 1991).

\section{RESULTS AND DISCUSSION}

\section{Carrot crop}

There was no significant interaction between the population densities of carrot and arugula in the shoot dry matter, root dry matter, total and commercial productivity and classified productivity of carrot. However, an adjustment to a response surface or simply a graph was adjusted between each characteristic and the densities of the components cultures.

A response surface to the dry mass of carrot shoots and roots was adjusted for the function of the population densities of carrot and arugula. An ascendant behavior of these characteristics was observed with increase in population densities of the component cultures, with maximum values of 4.94 and $4.06 \mathrm{tha}^{-1}$ observed in the combination of $100 \%$ of the RPSC for carrot with $100 \%$ of the RPSC for arugula (Figures $2 \mathrm{~A}$ and $2 \mathrm{~B}$ ). This result is partly due to the increase in the total population, due to the reduction in the spacing of the plants in the rows not being sufficient to achieve a level of strong competition and able to change the behavior of the dry mass of shoot and root. However, it is known that changes in the strength of the sources through a change in the planting density or through an increase in radiation availability, indirectly affect the dry matter distribution between plant organs (HEUVELINK, 1995a). The reduction of the forces of the plant sources at higher planting densities reduces the availability of photosynthate to the growth of the vegetative fraction (leaves), and thus reduces the availability to the generative compartment (roots), leading to a decrease in the proportion of the dry matter allocated to them (HEUVELINK, 1995b). Vegetative growth, represented by the dry matter production of shoots and roots of the culture was not affected by the change of the source strength resulting from the variations in population density.

The total and commercial productivity of carrot increased with increasing arugula population and decreasing carrot population, reaching the maximum values of 39.83 and $33.74 \mathrm{t} \mathrm{ha}^{-1}$ at the population density of $40 \%$ of the RPSC for carrot and $100 \%$ of the RPSC for arugula (Figures $2 \mathrm{C}$ and 2D), respectively. This productivity behavior shows that there was a strong interspecific competition, probably due to the high population density of arugula, which made the best use of the environmental resources.

Different results were obtained by Bezerra Neto et al. (2005), who observed a total productivity maximum of $40.72 \mathrm{t} \mathrm{ha}^{-1}$ in the combination of $100 \%$ of the RPSC for carrot and $100 \%$ of the RPSC for lettuce. For the carrot commercial productivity, the maximum value of $37.13 \mathrm{t} \mathrm{ha}^{-1}$ was obtained from the combination $100 \%$ of the RPSC with $40 \%$ of the RPSC for lettuce. According to these authors, the highest total and commercial productivity of carrot, obtained with increasing population density of carrot, is directly related to the larger number of plants per area. Lima et al. (2007) state that as the spacing decreases and population density increases there is an increase in total production per area, within certain limits. 
$\mathbf{A}$

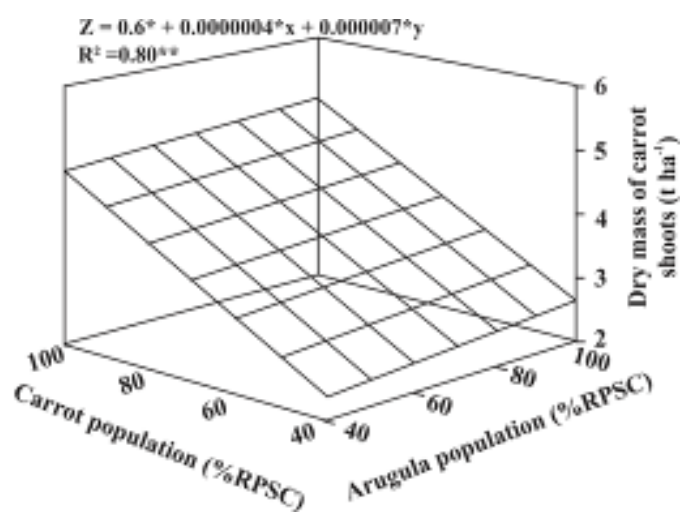

C

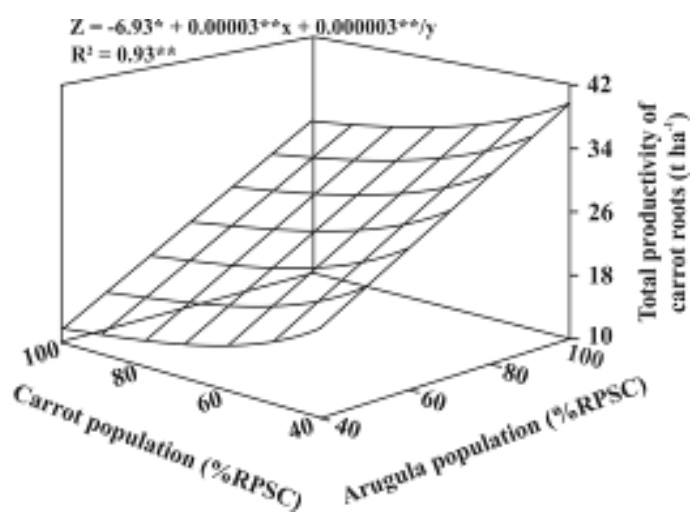

B

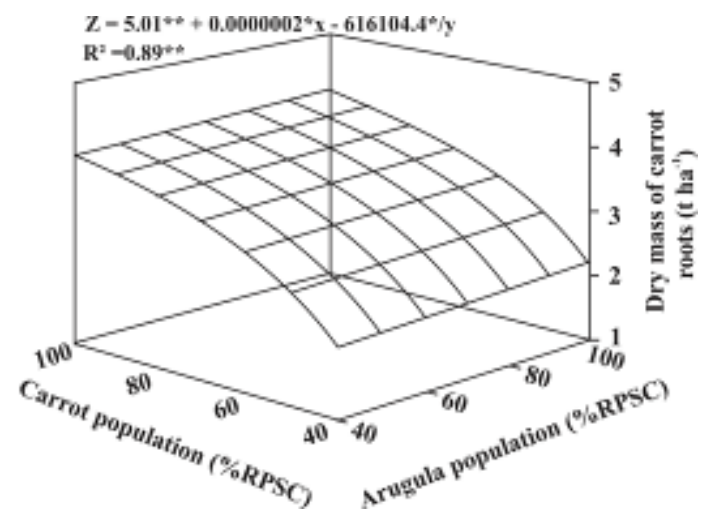

D

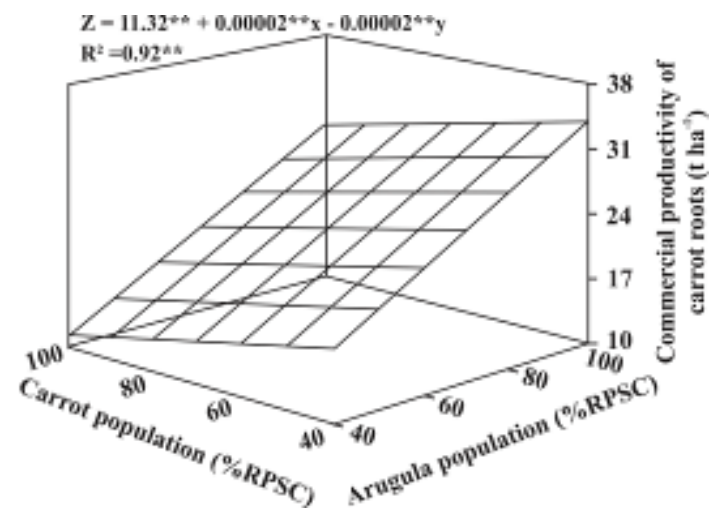

$\mathbf{E}$

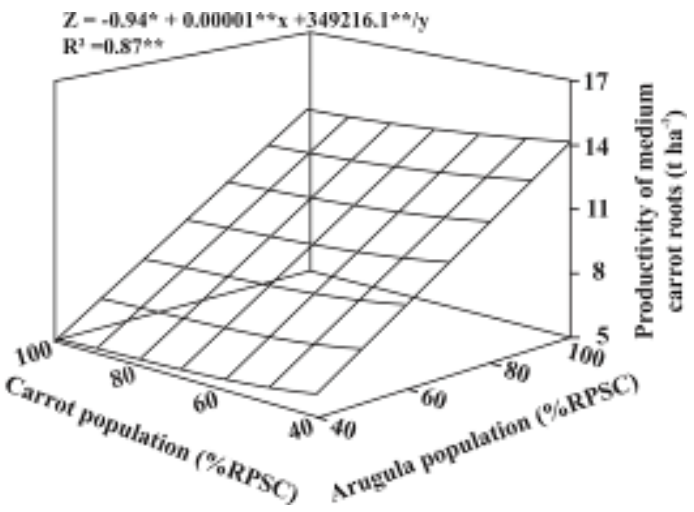

Figure 2. Dry mass of shoots (A), dry mass of roots (B), total (C) and commercial productivity of roots (D), and productivity of medium carrot roots (E) intercropped with arugula in bicropping under different population density combinations of the component crops. Mossoró, RN, UFERSA, 2012.

For medium root productivity of carrot an adjustment of a response surface as a function of the growing arugula population and decreasing carrot population was obtained, reaching a maximum value of $13.90 \mathrm{t} \mathrm{ha}^{-1}$ in the combination of $40 \%$ of the RPSC for carrot with $100 \%$ of the RPSC for arugula (Figure 2E). On the other hand, there was no adjustment of a response surface for the productivity of short, long, or scrap roots, and there was a simple regression between each productivity and the population densities of the component crops.

For the productivity of short roots, a quadratic behavior was observed, with an increase in this variable as a function of carrot population, obtaining a maximum value of $4.38 \mathrm{t} \mathrm{ha}^{-1}$ at a population density of $74.4 \%$ of the RPSC of carrot, decreasing until the largest population density of carrot studied (Figure 3A). Differently, the productivity of short roots increased with growing arugula population up to a maximum of $5.92 \mathrm{t}$ ha- 1 in the population density of $100 \%$ of the RPSC (Figure 3B).

Long root productivity decreased with increasing population density of carrot and increased with increasing arugula density, with maximum values of 12.68 and $10.94 \mathrm{t} \mathrm{ha}^{-1}$, at the lowest density of carrot and highest density of arugula, respectively (Figures 3C and 3D). This behavior in the long roots shows a stronger intraspecific competition for the 
carrot culture, since the roots in the soil had a smaller area available to capture the nutrients necessary for their growth and thus influence the quality and productivity of the crop.

According to Lima et al. (2007), a higher planting density causes increased competition for water, light and nutrients. As the quantities of nutrients provided were similar for all treatments, there was less availability of these nutrients in the treatments with higher numbers of plants.

A

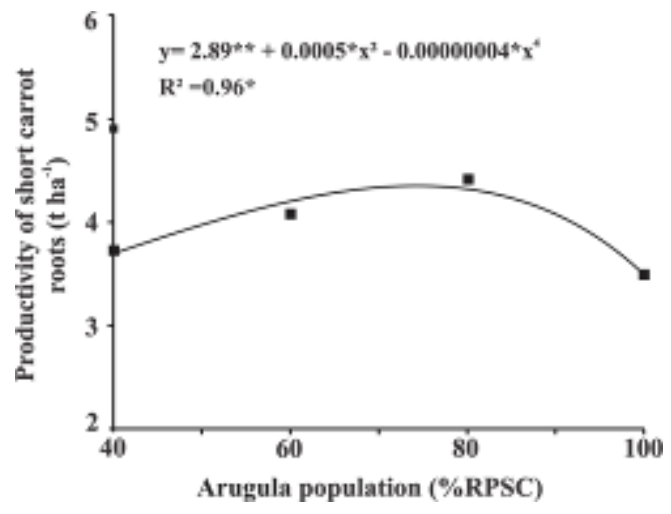

C

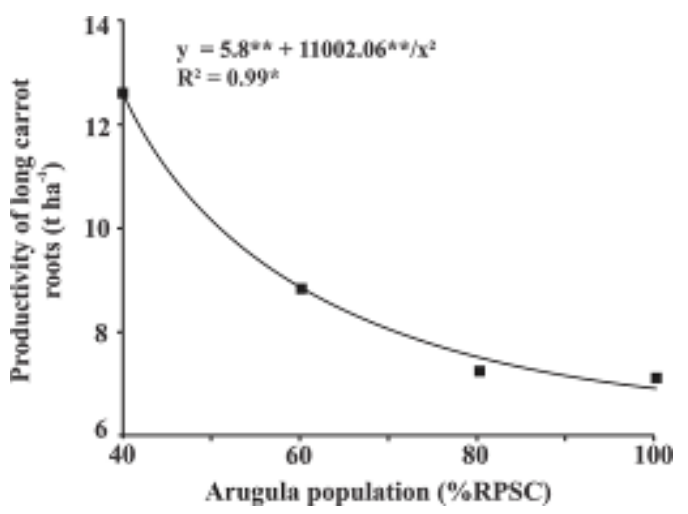

$\mathbf{E}$

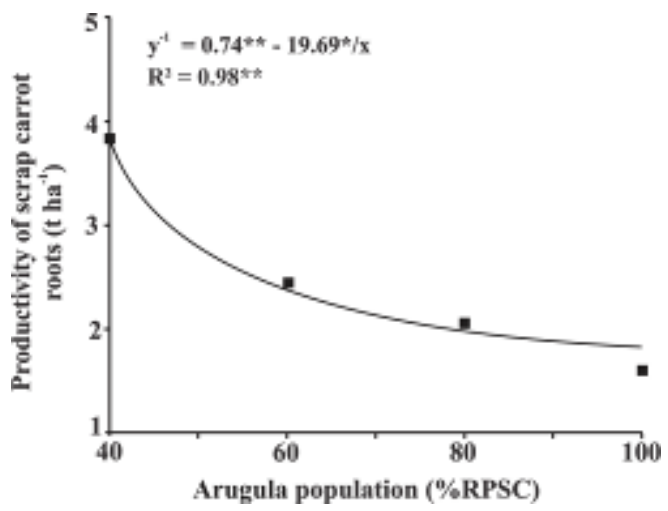

For the scrap roots, there was a similar behavior to the productivity of long roots as a function of the population density of carrot with a maximum value of $3.92 \mathrm{tha}^{-1}$, at a density of $40 \%$ of the RPSC for carrot (Figure 3E). By contrast, a quadratic behavior was found for this variable, with a maximum value of $3.95 \mathrm{tha}^{-1}$ of scrap roots at a population density of $88.5 \%$ of the RPSC for arugula (Figure 3F).

\section{B}

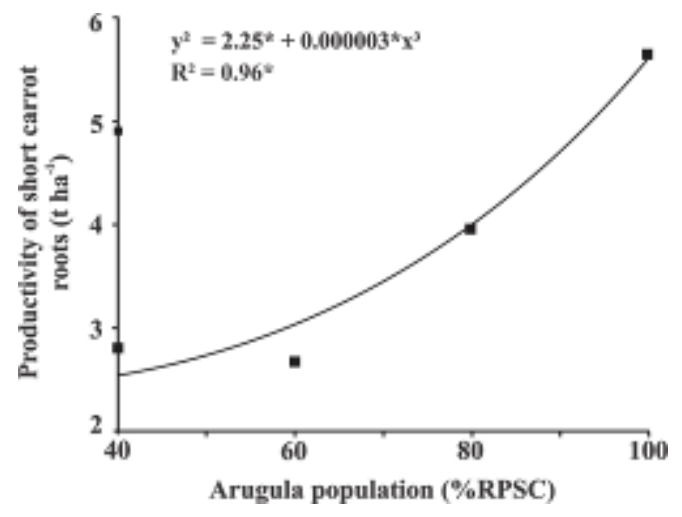

D

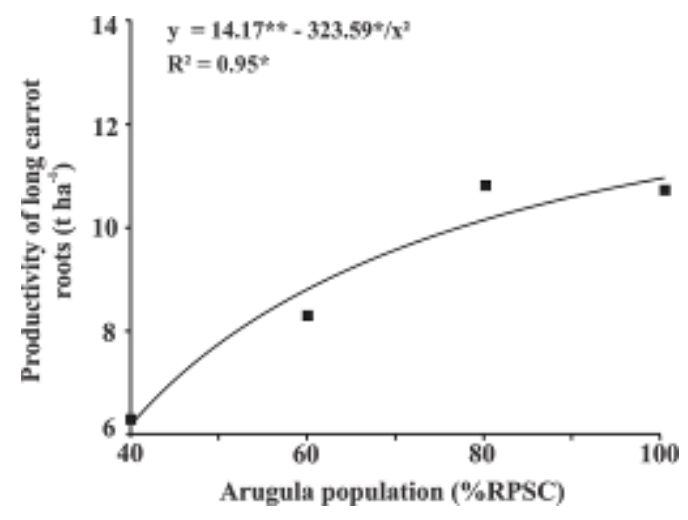

F

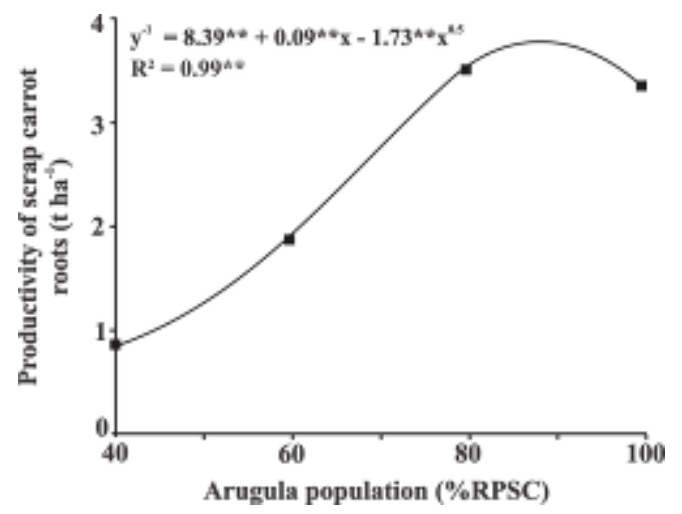

Figure 3. Productivity of short, long and scrap roots of carrot intercropped with arugula in bicropping as a function of carrot (A, C and E) and arugula (B, D and F) population density. Mossoró, RN, UFERSA, 2012.

The response to the population of arugula was probably due to low interspecific competition within certain limits. Lopes et al. (2008) report that higher population densities of carrot cause a reduction in the diameter and size of roots. It is known, however, that an increase in the density of carrot can influence the 
quality of the tuberous roots, increasing the number of fine roots and reducing the average size of the roots due to increased competition for water and nutrients. Increased density can also influence the aerial parts of the plant, increasing the production of branches (OLIVEIRA, 2012).

\section{Arugula crop}

There was no significant interaction between population densities of carrot and arugula on the green and dry mass yields of shoots of arugula in both cultivations. However, a response surface was adjusted to these arugula characteristics as a function of the population densities of carrot and arugula, which registered an increase in these variables with the growing population density of arugula and decreasing density of carrot. Maximum values of 8.06 and $1.42 \mathrm{t} \mathrm{ha}^{-1}$ were observed in the combination of $40 \%$ of the RPSC for carrot with $100 \%$ of the RPSC for arugula in the first cropping (Figures 4A and 4B).
A

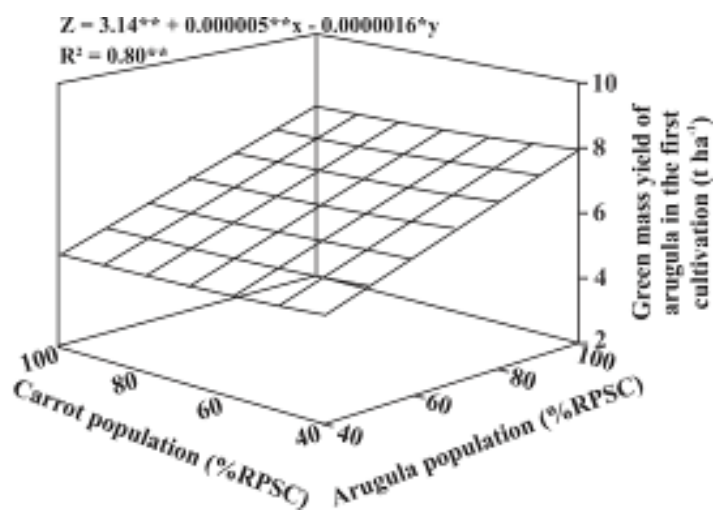

C

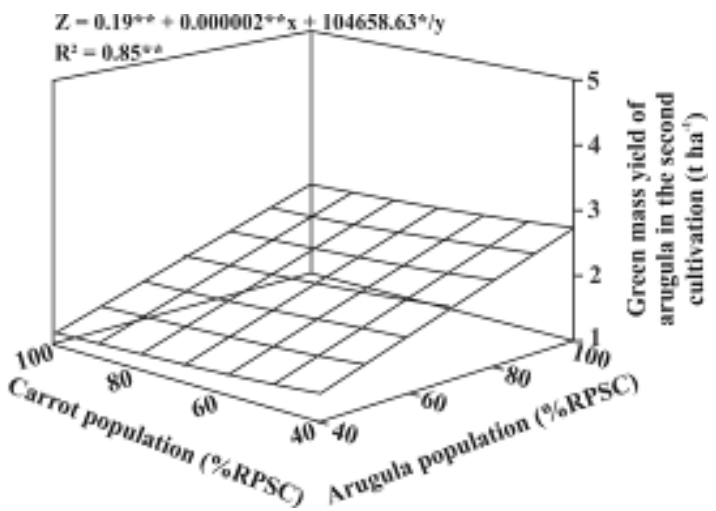

B

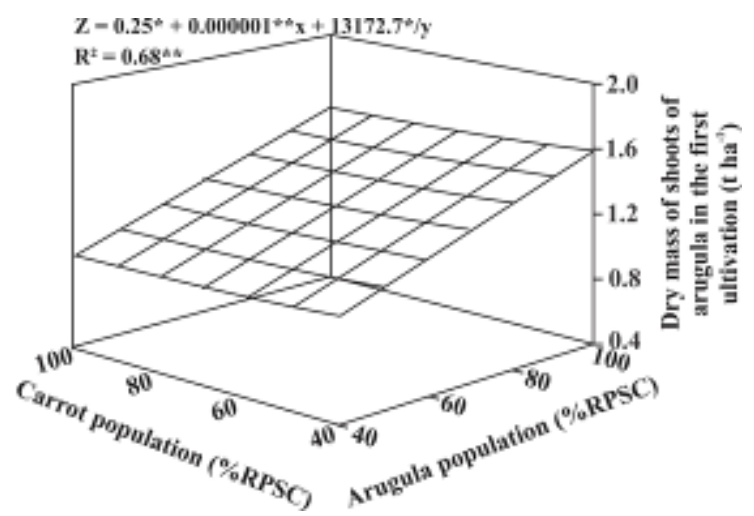

D

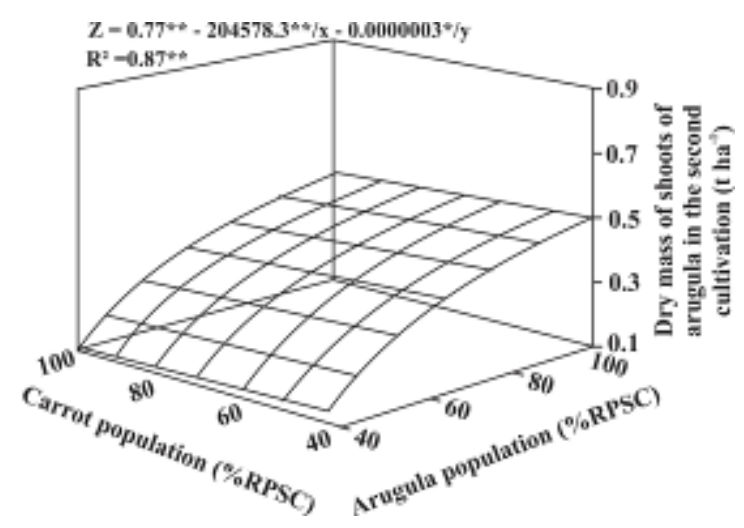

$\mathbf{E}$

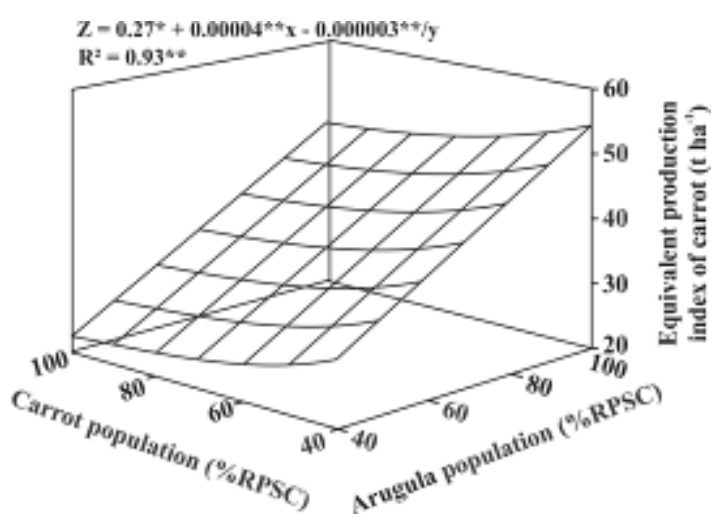

Figure 4. Green mass yield and dry mass of shoots of arugula in the first (A and B) and second cultivation (C and D) and the equivalent production index of carrot $(\mathrm{E})$ intercropped with arugula under different population combinations. Mossoró, RN, UFERSA, 2012. 
These results were directly influenced by the greater number of arugula plants present in exploration of the cultures, and consequently, by its greater leaf area, since, according to Trenbath (1976), the production of dry plant matter, especially in broadleaved plants depends on of the efficiency in the interception of the photosynthetically active radiation by the crop involved in the intercropping.

These same characteristics increase with decreasing population density of carrots and growth of the arugula in the second cultivation, registered the maximum values of 2.67 and $0.5 \mathrm{t} \mathrm{ha}^{-1}$, also in the combination of $40 \%$ of the RPSC for carrot with $100 \%$ of the RPSC for arugula, respectively (Figures $4 \mathrm{C}$ and $4 \mathrm{D}$ ). In this arugula cultivation, the culture of carrot was already established, causing shading of the arugula, thus increasing the competition between the cultures and decreasing the arugula production compared with the first cultivation (LIMA et al., 2013). The decrease in these characteristics obtained from the second cultivation compared with the first crop is probably due to higher interspecific competition, particularly with respect to solar radiation due to the shading exercised by the carrot on arugula, since the arugula was planted when the carrot was already ninety days after sowing. Generally, when a higher plant shades a lower plant, the competition established causes decreased growth and development of the smaller plant (OFORI; STERN, 1987).

For the equivalent production index of carrot (EPIc), there was an upward linear behavior with increasing population density of arugula and decreasing carrot population density, reaching a maximum of $53.39 \mathrm{t} \mathrm{ha}^{-1}$ at the combination of $40 \%$ of the RPSC for carrot and $100 \%$ of the RPSC for arugula (Figure 4E). This result allows us to infer that the combination of populations at optimized densities provides more agronomically productive and efficient intercropping systems, with high quality products.

\section{CONCLUSIONS}

The highest agronomic efficiency for intercropping of carrot and arugula in bicropping was achieved at the combination of $40 \%$ of the RPSC for carrot and $100 \%$ of the RPSC for arugula.

The maximum commercial productivity (33.74 $\mathrm{t} \mathrm{ha}^{-1}$ ) of carrot roots and the green mass maximum yields (8.06 and $2.67 \mathrm{t} \mathrm{ha}^{-1}$ ) of arugula in both cultivations were also obtained with population densities of $40 \%$ of the RPSC for carrot and $100 \%$ of the RPSC for arugula.

\section{REFERENCES}

BARROS JÚNIOR, A. P. et al. Desempenho agronômico do bicultivo da alface em sistemas consorciados com cenoura em faixa sob diferentes densidades populacionais. Horticultura Brasileira, Brasília, v. 23, n. 3, p. 712-717, 2005.

BEZERRA NETO, F. et al. Associação de densidades populacionais de cenoura e alface no desempenho agronômico da cenoura em cultivo consorciado em faixa. Horticultura Brasileira. Brasília, v. 23, n. 2, p. 233-237, 2005.

BEZERRA NETO, F. et al. Assessment of agroeconomic indices in polycultures of lettuce, rocket and carrot through uni - and multivariate approaches in semi-arid Brazil. Ecological Indicators, Amsterdam, v. 14, n.2, p. 11-17, 2012.

CECÍLIO FILHO, A. B.; MAY, A. Produtividade das culturas de alface e rabanete em função da época de estabelecimento do consórcio. Horticultura Brasileira, Brasília, v. 20, n. 3, p. 501-504, 2002.

FREITAS, K. K. C. et al. Desempenho agronômico de rúcula sob diferentes espaçamentos e épocas de plantio. Revista Ciência Agronômica, Fortaleza, v. 40, n. 3, p. 449-454, 2009.

GLIESSMAN, S. R. Agroecology: ecological processes in sustainable agriculture. Ann Arbor Press, Chelsea, Michigan, USA, 1998. 357 p.

HATFIELD，J. L.;KARLEN， D. L. Sustainable agriculture systems. Boca Raton, Lewis Publishers/ CRC Press, Iowa, USA, 1994. 336 p.

HEUVELINK E. Effect of plant density on biomass allocation to the fruits in tomato (Lycopersicum esculentum Mill). Scientia Horticulturae, Amsterdam, v. 64, n. 4, p. 193-201, 1995a.

HEUVELINK E. Influence of sink-source interaction on dry matter production in tomato. Annals of Botany, Amsterdam, v. 75, n. 3, p. 381-389, 1995 b.

JANDEL SCIENTIFIC. Table Curve: curve fitting software. 2 ed. Corte Madera, CA: Jandel Scientific, 1991. $280 \mathrm{p}$.

LIMA, J. S. S. et al. Desempenho agroeconômico de coentro em função de espaçamentos e em dois cultivos. Revista Ciência Agronômica, Fortaleza, v. 38, n. 4, p. 407-413, 2007.

LIMA, J. S. S. et al. Produtividade da cenoura, coentro e rúcula em função de densidades populacionais. Revista Verde de Agroecologia e Desenvolvimento Sustentável, Mossoró, v. 8, n. 1, p. 110-116, 2013. 
LINHARES, P. C. F. et al. Produção de fitomassa e teores de macronutrientes da jitirana em diferentes estágios fenológicos. Revista Caatinga, Mossoró, v. 21, n. 4, p. 72-78, 2008.

LOPES, W. A. R. et al. Produtividade de cultivares de cenoura sob diferentes densidades de plantio. Revista Ceres, Viçosa, v. 55, n. 5, p. 482-487, 2008.

MAHAPATRA, S. C. Study of grass-legume intercropping system in terms of competition indices and monetary advantage index under acid lateritic soil of India. American Journal of Experimental Agriculture, Delaware, v. 1, n. 1, p. 1-6, 2011.

MAZAHERI, D.; MADANI, A.; OVEYSI, M. Assessing the land equivalent ratio (LER) of two corn (Zea mays L.) varieties intercropping at various nitrogen levels in Karaj, Iran. Journal of Central European Agriculture, Khosestan, Iran, v. 7, n. 2, p. $359-364,2006$.

MONTEZANO, E. M.; PEIL, R. M. N. Sistemas de consórcio na produção de hortaliças. Revista Brasileira de Agrociência, Pelotas, v. 12, n. 2, p. 129-132, 2006.

MOUSAVI, S. R.; ESKANDARI, H. A general overview on intercropping and its advantages in sustainable agriculture. Journal of Applied Environmental and Biological Sciences, Egypt, v. 1, n. 11, p. $482-486,2011$

OFORI, F.; STERN, W. R. 1987. Cereal-legume intercropping systems. Advances in Agronomy, New York, v. 41, n. 1, p. 41-90, 1987.

OLIVEIRA, M. K. T. et al. Desempenho agronômico da cenoura adubada com jitirana antes de sua semeadura. Revista Ciência Agronômica, Fortaleza, v. 42, n. 2, p. 364-372, 2011.

OLIVEIRA, L. J. Viabilidade agroeconômica do bicultivo de rúcula e coentro consorciado com cenoura em função de quantidades de jitirana e densidades populacionais. 2012. 102f. Tese (Doutorado em Fitotecnia: Área de Concentração Agricultura Tropical) - Universidade Federal Rural do Semi-Árido, Mossoró-RN, 2012.

PORTO, V. C. N. et al. Combination of lettuce and rocket cultivars in two cultures intercropped with carrots. Horticultura Brasileira, Brasília, v. 29, n. 3, p. 404-411, 2011.

RAMALHO, M. A. P.; OLIVEIRA, A. C.; GARCIA, J. C. Recomendações para o planejamentoe análise de experimentos com as culturas demilho e feijão consorciadas. Sete Lagoas: EMBRAPA/CNPMS. 1983. 74 p.
(Documentos, 2).

SANTOS, R. H. S. Interações interespecíficas em consórcios de olerícolas. 1998.129f. (Doutorado em Agronomia: Área de concentração Fitotecnia) Universidade Federal de Viçosa, Viçosa-MG, 1998.

SOUZA, J. L. et al. Manual de horticultura orgânica. Ed. Aprenda Fácil, Viçosa-MG, 2003. 564 p.

TRENBATH, B. R. Plant interactions in mixed crops communities. In: PAPENDICK, R. I.; SANCHEZ, P. A. e TRIPLETT, G. B. (Eds). Multiple cropping. Madison: American Society of Agronomy, 1976. p. 129-160

VIEIRA, J. V. et al. Esplanada: cultivar de cenoura de verão para fins de processamento. Horticultura Brasileira, Brasília, v. 23, n. 3, p. 851-852, 2005. 